\title{
Fluorescence methods for estimation of post-fire response of pine needles
}

\author{
Irina G. Gette ${ }^{1} \bowtie$, Nina V. Pakharkova ${ }^{1}$, Ivan V. Kosov ${ }^{2}$, Irina N. Bezkorovaynaya ${ }^{1}$ \\ ${ }^{1}$ Siberian Federal University, 79 Svobodny, Krasnoyarsk 660041, Russia, e-mail: GetteIrina@yandex.ru \\ ${ }^{2}$ Sukachev Institute of Forest SB RAS, Federal Research Center "Krasnoyarsk Science Center of SB RAS", \\ 50 Akademgorodok, Krasnoyarsk 660036, Russia
}

\section{Abstract}

Forest fire represents one of the most serious abiotic stress factors that influence the function and productivity of ecosystems globally. Siberian pine forests are often exposed to forest fires, but they are not always harmful to them. This paper discusses the possibility of using fluorescent methods to assess the thermal effects on the assimilation apparatus of Scots pine (Pinus sylvestris L.) needles. The assimilation apparatus of pine needles was reestablished after exposure to convective, simulating the effect of ground fire heat flow, though the recovery rate depends on the impact force. The analysis of fast and delayed fluorescence characteristics revealed differences in the thermostability of the Scots pine needles showing certain modification of physiological processes in plants under the influence of stress factors with a positive acclimation effect. The Scots pine needles grown after ground fire are more resistant to the recurrent sublethal temperature, and this effect is maintained during the next growing season. This paper suggests that reforestation planning, particularly burning (low-intensity fire), will result in improved tree physiology that will lead to an increase in Scotch pine survival rate due to repeated heat stresses. Furthermore, the fluorescence method can be used to diagnose the thermic resilience of pine needle and assess high-temperature effects.

\section{KeY WORDS}

fluorescence, forest fires, heat stress, Pinus sylvestris, resilience, Siberia

\section{INTRODUCTION}

Forest fires are one of the main recurrent factors that have a significant impact on forest ecosystems throughout the world. Being characterized by highly frequent fires, the boreal forest fires have always remained a major evolutionary factor. Annually, from 4500 to 27,000 forest fires occur in forest and steppe zones of Siberia, most of them being ground fires (Ivanova et al. 2014). In the recent decades there has been seen a close correla- tion between the air temperature dynamics and the total number of forest fires, which is reflected in the increase of the damage area (Ponomarev et al. 2012; Kharuk and Ponomarev 2016). The distribution of forest fires in Siberia is uneven, and they happen mainly in the areas occupied by light coniferous taiga, which may be related to the intensity and duration of droughts in the taiga subzones (Valendik et al. 2014).

Most studies have shown that forest fires influence forest stands not only directly, but also through unmedi- 
ated habitat alteration. Fires disrupt the natural balance between the individual components of ecosystems and make considerable changes in the appearance of today's forests. They cause changes of tree species, affect the age structure of forest stands, and alter and violate the species composition of the grass-shrub layer (Tsvetkov 2013; Kovaleva et al. 2013; Francos 2016). They lead to a disruption of the natural soil structure and cause changes in power and even morphological characteristics of genetic horizons (Turetsky and Wieder 2001; Tsibart and Grennadyev 2008; Certini 2005). After the fire subsides or is extinguished, environmental conditions change rapidly, resulting in improved temperature control, accompanied by the permafrost degradation and mineralization of soil organic matter, which entails the increasing amount of available moisture and nutrients, and as a consequence, the progressive radial growth of trees for a few subsequent years (McRae et al. 2006; Bezkorovainaya et al. 2007; Tarasov et al. 2008; Smits 2016).

Currently, much attention is paid to the study of adaptive responses and mechanisms of plant resistance to various stress factors. The impact of high temperatures on the vegetative organs during forest fires may be considered as an extreme stress factor with a short duration of action. Many authors demonstrate in their works that under the influence of high temperatures plants go through multiple structural and functional changes, among which changes in the photosynthetic apparatus is fairly important (Titov and Talanov 2010; Wang and $\mathrm{Hu}$ 2013).

Some researchers are devoted to studying the impact of heat stress on the electron transport system, functioning of photosystems, photosynthetic activity, gas exchange and chlorophyll fluorescence in plants (Owen and Mark 2003; Wang and $\mathrm{Hu}$ 2013). It is known that photosynthesis is one of the physiological processes most sensitive to heat, so even a short-term temperature rise due to ground fire can become a significant stress factor for them (Yamori et al. 2014). The damage to photosystems is often the first reaction to the thermal stress. A method for detecting the chlorophyll fluorescence is a convenient and promising way of getting information about the primary reactions of photosynthesis, which allows researchers to quickly estimate the impact of extreme temperatures on the needle mesophyll; it is believed that the state of the photosynthetic apparatus largely corresponds to the general state of the plant.
In addition to substantial cellular protection mechanisms against heat shock, there are some other factors that lead to morphological adaptations of plants. In particular, the thickness of the protective layer of dead bark plays a momentous role in the protection of live stem tissues from thermal damage (Valendik et al. 2006). On this basis, the most resistant to fire species are larch and pine. Apart from that, the key fire resistance factors of wood species normally include the species of tree, the tree age, height, diameter and location of the crown.

Nowadays, the main task is not only to define a parameter that can be used to assess the sensitivity of photosynthesis to heat stress, but also to estimate the preservation of acclimation effects of trees after exposure to fire. So the purpose of our study was to determine the possibility of using fluorescent methods to determine the photosynthetic activity and the assimilation apparatus ability of needles to recover after Scots pines were subjected to heat stress during ground fire.

\section{Material AND methods}

\section{Study area and objects}

In a fire it is the tree crown that is directly exposed to short-term convection heat. According to G.I. Girs (1982), during the combustion the crown temperature, depending on combustion intensity, can range from $33^{\circ} \mathrm{C}$ (ground fire of low intensity) to $52^{\circ} \mathrm{C}$ (crawling ground fire of medium intensity).

For experiments on modeling convective flow to simulate the effect of ground fire, we used 15- to 25-year-old saplings of Scots pine, grown outside the city of Krasnoyarsk. Collecting of saplings (branches of the lower part of the crown) was carried out in a single day. The branches in a jar with water were delivered to the laboratory within $1 \mathrm{~h}$.

Attention is commonly paid to studying plants' adaptive responses to heat stress, while the ability of plants to recover under stress conditions has been studied to a lesser extent so far. Comparing the samplings of Pinus sylvestris L., growing in the same climatic and soil conditions, but differing in the duration of post-fire period, we could distinguish acclimation effects appearing after the stress.

The studied area was located in a forest-steppe zone of Krasnoyarsk region in the territory of "Po- 
Table 1. Characteristics of sample plots (SP)

\begin{tabular}{|c|c|c|c|c|c|c|c|}
\hline \multirow{2}{*}{ № SP } & \multirow{2}{*}{$\begin{array}{c}\text { Forest } \\
\text { stand }\end{array}$} & $\begin{array}{c}\text { Diameter } \\
{[\mathrm{cm}]}\end{array}$ & $\begin{array}{c}\text { Height } \\
{[\mathrm{m}]}\end{array}$ & $\begin{array}{c}\text { Height up } \\
\text { to the crown [m] }\end{array}$ & $\begin{array}{c}\text { Strength, type of fire/ } \\
\text { height of scorch [cm] }\end{array}$ & $\begin{array}{c}\text { Fire } \\
\text { period }\end{array}$ & $\begin{array}{c}\text { Growth class/ } \\
\text { estimate productivity/ } \\
\text { fullness }\end{array}$ \\
\hline SP1 & 10 Pines & $11.7 \pm 1.1$ & $7.8 \pm 0.4$ & $2.9 \pm 0.2$ & $\begin{array}{c}\text { weak ground/ } \\
\mathrm{h}=23.0 \pm 9.0\end{array}$ & May 2014 & $\mathrm{I} / \mathrm{Ia} / 0.6$ \\
\hline SP2 control & 10 Pines & $12.0 \pm 1.6$ & $7.9 \pm 0.6$ & $3.0 \pm 0.2$ & - & - & \\
\hline
\end{tabular}

gorelskiy bor" station of Sukachev Forest Institute, Siberian Branch of the Russian Academy of Sciences (56 $\left.22^{\prime} 07.48^{\prime \prime} \mathrm{N} 92^{\circ} 57^{\prime} 17.95^{\prime \prime} \mathrm{E}\right)$.

The object of research was studying pine saplings (I age class) rich in herbs forest with abundant pleurocarpous moss. The area for sampling selected for the study was the land plot where the ground fire was occurred in 2014. The control sample for comparison was the plot that was not exposed to fire (Tab. 1). Ground fire intensity was measured by the average height of scorch (a charred bark surface) on the tree trunks (Kurbatsky 1962; Tsvetkov 2006).

From each plot eight model trees were chosen that grow in the same conditions with the same characteristics of moisture, light, and viability, with no visible damage from xylophagous insects or dieback. Collection of saplings from all the studied sites was carried out in a single day (Grigoriev and Andreev 2012). A lopper was used to cut three branches from the lower part of the crown of each tree (average height of sapling was $2.5 \mathrm{~m}$ ). The cut saplings in the jar with water were delivered to the laboratory within 1 hour.

\section{Research methods}

Since the determination of the crown temperatures during the fire is methodologically quite difficult, all the experiments were performed on the cut branches. The method involves heating not individual needles, but cut branches from the trees under investigation. According to authors (Akres et al. 2016), branches and water retained approximately $68 \%$ of their original photosynthetic health after 27 days. Since branches from experimental and control trees were in the same conditions, the decrease in photosynthetic activity does not affect the ratio of experience and control.

Heating of samples was modeled by convective heat transfer from the flame of a gas burner with constant burning intensity. The duration of heating was 2,5 and 10 minutes at temperatures of $45^{\circ} \mathrm{C}, 50^{\circ} \mathrm{C}$ and $55^{\circ} \mathrm{C}$.

To create a sustainable convective flow with set temperature, we used the following installation (Fig. 1), where the gas burner gave rise to convective flow. Installation allows one to create a steady convective flow, which simulates the fire impact on a tree branch (Valendik and Kosov 2008).

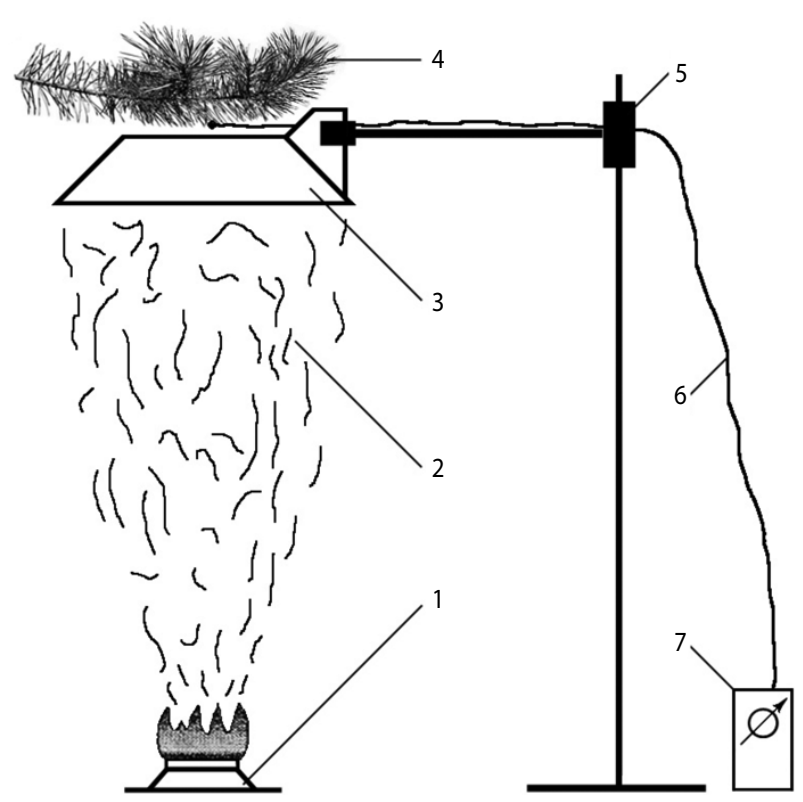

Figure 1. Convection Heater Installation for Samples: 1 - gas burner, 2 - convective flow, 3 - flow regulator, 4 - sample, 5 - stand with holder, 6 - thermocouple, 7 - dataloger

The sampling (4) was fastened horizontally on the flow regulator (3), and the thermocouple (6) was fixed directly under the sapling in the center flow where the temperature corresponded to the set one. The flow temperature was recorded at intervals of $1 \mathrm{~s}$.

To measure the flow temperature per unit time we used autonomous dataloger EClerk-USB-K with the 
measuring element of prefabricated chromel-alumel thermocouple (ТП.AХ (K)-K11).

To evaluate the photosynthetic productivity of forest stands in vivo and in laboratory, one must have a component that can serve as a characteristic of the photosynthetic activity. When examining eco-physiological photosynthesis, fast fluorescence parameters can act as such indicators (Molchanov 2012). Fast fluorescence parameters were measured before (control measurement) and immediately after the influence of convective heat flow by fluorometer Junior-PAM (Walz, Germany) for pulse-amplitude modulated fluorometry. The ratio of $F_{\mathrm{v}} / F_{\mathrm{m}}$ was used as an estimate of the maximum quantum yield of photosystem II photochemistry (Maxwell and Johnson 2000). Fluorescence parameters were calculated using WinControl program. Measurements were carried out in five biological and three analytical replications for each temperature and heating time.

To assess the stability of needles in terms of post-fire conditions, fast $\left(F_{\mathrm{v}} / F_{\mathrm{m}}\right)$ and delayed fluorescence relative parameters were taken into account, as they show the photosynthetic activity of the needles. Parameters of delayed fluorescence were measured by fluorometer "Photon-10," taking into consideration the guidelines for the selection and analysis of the Scots pine needles (Grigoriev et al. 1996; Grigoriev and Andreev 2012).

To determine the stability of woody plants to high temperatures and their reestablishment in the post-fire period, we applied method of artificial stress exposure, heating needles at temperatures higher than their physiological optimum. According to the data obtained in experiments on convective heating of needles, the authors observed reversible inhibition of photosynthesis with the gradual recovery process at temperatures up to $55^{\circ} \mathrm{C}$, which is consistent with G.I. Girs's results (1982). During the experiment, heating of the cut branches with the lower parts immersed in the water containers was performed in climatostat (climate chamber) equipped with an internal fan for uniform heating of samples at sublethal temperatures $-43^{\circ} \mathrm{C}, 45^{\circ} \mathrm{C}$ and $47^{\circ} \mathrm{C}$. These temperatures did not lead to the shrinkage of needles. The duration of heating was $10 \mathrm{~min}$ and then fluorescence indicators were immediately measured.

After heating in climatostat and on convective heater, the saplings were left under laboratory conditions at relative humidity of $\approx 60 \pm 5 \%$ and air temperature of $\approx 24 \pm 2{ }^{\circ} \mathrm{C}$. After that, the recovery of their photosyn- thetic activity was observed during 4 days; thus, it was possible to detect the thermostability of needles, the ability of cells to activate defense mechanisms and to resist heat damage, which determines wood resilience during fire and after it (Lange 1964).

The concentration of photosynthetic pigments was measured in the biennial needles by spectrophotometer SPEKOL1300 Analytik Jenna AG after extraction in $85 \%$ acetone (Gavrylenko and Zhigalova 2003). The measurement was conducted at an average sample of each model tree with three promptitude parameters.

Statistical analysis was performed by STATISTICA 9 software. Statistically significant differences were determined by Student's $t$-test where $p \leq 0.05$.

\section{Results AND DISCUSSION}

Photosynthesis is a thermolabile process where suppression occurs at relatively low temperatures. According to research studies, it has a high capacity for repairing the damage. PSII is considered to be the most vulnerable part of the photosynthetic apparatus (Murata et al. 2007). As a consequence, changes in photosynthetic activity during exposure to high temperatures and after such exposure may signal the functional stability of the assimilation apparatus.

The study of thermostability of biennial Scots pine needles showed that temperatures of $45^{\circ} \mathrm{C}$ and $50^{\circ} \mathrm{C}$ are not lethal to cells regardless of the heating duration. Thus, the effect of a temperature of $45^{\circ} \mathrm{C}$, which exceeds the photosynthetic optimum of photosynthesis, did not have a significant impact on the maximum quantum yield of PSII photochemistry, the values of which remained the same throughout the laboratory exposure proving that at low-intensity exposure to heat there can be a direct continuation of photosynthetic activity.

Reversible photoinhibition followed by a gradual recovery process was observed at $50^{\circ} \mathrm{C}$, but the important factor was the duration of heat exposure. So after 5-min heating at $50^{\circ} \mathrm{C}$ the level of reparation for the next 3 days was higher than that after 10-min warmingup at the same temperature, while a short 2-min heating at $50^{\circ} \mathrm{C}$ did not lead to any noteworthy suppression of the indicator against the control measurement.

After exposure to sublethal temperature of $55^{\circ} \mathrm{C}$ for 5 and $10 \mathrm{~min}$ (Fig. 2), there was a sharp decrease in the 

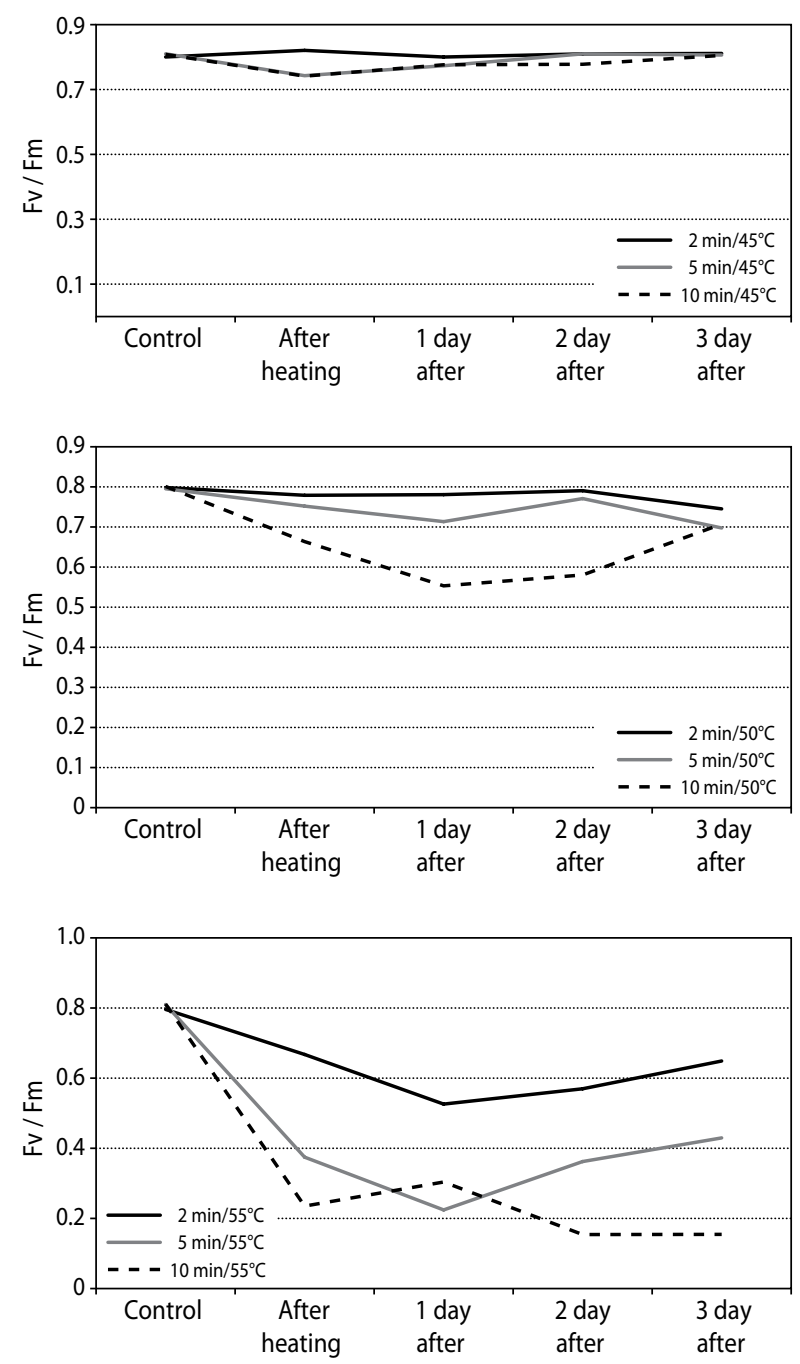

Figure 2. Changes in fast fluorescence after needles' exposure to convective flow

fast fluorescence parameter, which was on average 55\% and $72 \%$ against the control level. During experimental day 3 of laboratory exposure, photosynthesis repair was detected; it was almost the initial level but only for the needles after 2 -min heating at temperature $55^{\circ} \mathrm{C}$. On the third day after 5-min heating photosynthesis gained $50 \%$ of the initial intensity. The irreversible reduction in photochemical activity of PSII occurred only after 10 -min heating at $55^{\circ} \mathrm{C}$, followed by the complete drying of needles a day after heating.

Thus, the observations showed that photosynthesis in pine needles is relatively resistant to the damaging effects of high temperatures. Repair of photosynthetic activity took place after a partial suppression at temperatures of $45^{\circ} \mathrm{C}, 50^{\circ} \mathrm{C}$ and $55^{\circ} \mathrm{C}$. As regards the recovery speed of photosynthesis, the important factor was the duration of damaging heating.

According to the cited studies, it was found that the temperature deviation from the optimum, typical of a species, affects the quality and quantity of pigment fund of the plastid apparatus, the structural organization of chloroplasts and their functional activity $(\mathrm{Su}-$ dachkova et al. 2016).

Heating of needles leads to a slight fall in the amount of chlorophyll and carotenoids (Fig. 3), which indicates the absence of degradation. Small changes in the content of pigments in the period after exposure to high temperatures depend on the heat intensity. So after short heating at $45^{\circ} \mathrm{C}$ and $50^{\circ} \mathrm{C}$ there is almost no decrease in the content of pigments against the control level. Under the stress influence on the needles at $55^{\circ} \mathrm{C}$ the amount of chlorophyll $\mathrm{a}+\mathrm{b}$ and carotenoids decreased by $30 \%$ on average from the control level on the day after heating. As a result, our studies showed plasticity of the Scots pine pigment apparatus in response to high temperatures, as well as the possibility of repair.

Therefore, during the experiments simulating the effect of ground fire and conducted to study the impact of convective flow on the Scots pine assimilation apparatus, the thermal stability of the needles was detected. During registration of fast fluorescence parameters and

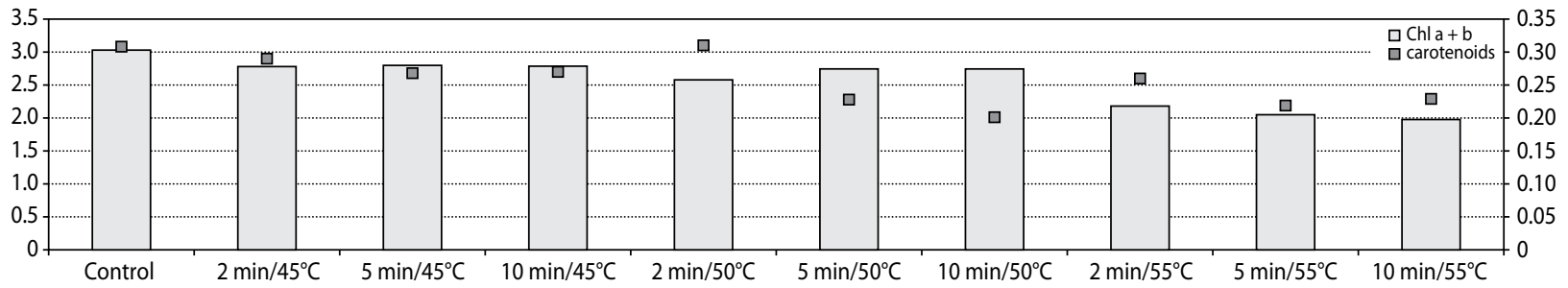

Figure 3. Changes in the chlorophyll $\mathrm{a}+\mathrm{b}$ and carotenoids content a day after heating, $\mathrm{mg} / \mathrm{g}$ of dry weight (control level - the original content of pigments prior to the exposure to high temperatures) 
A

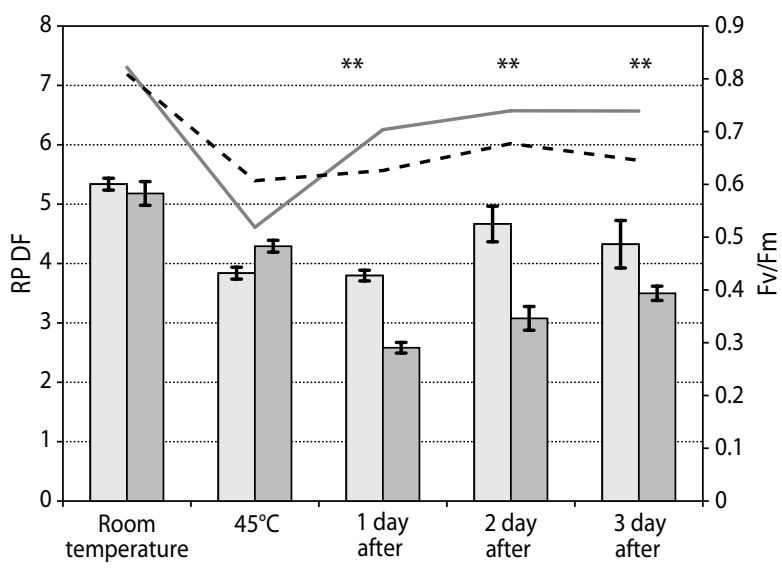

B

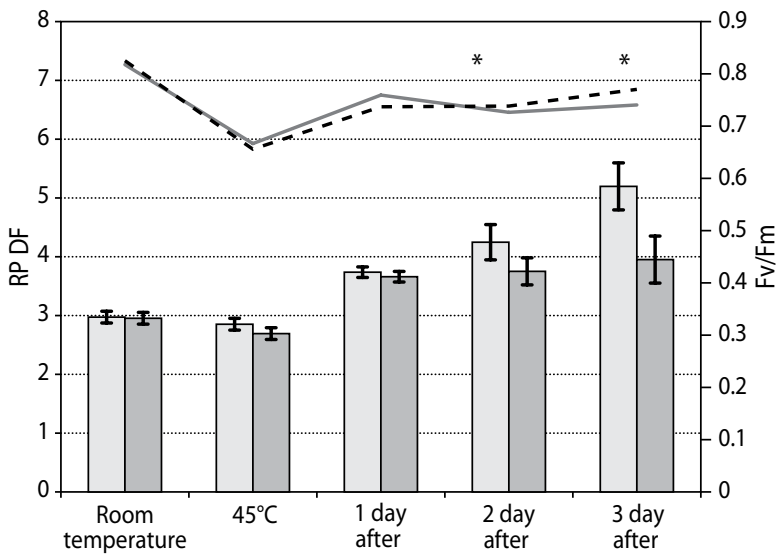

C

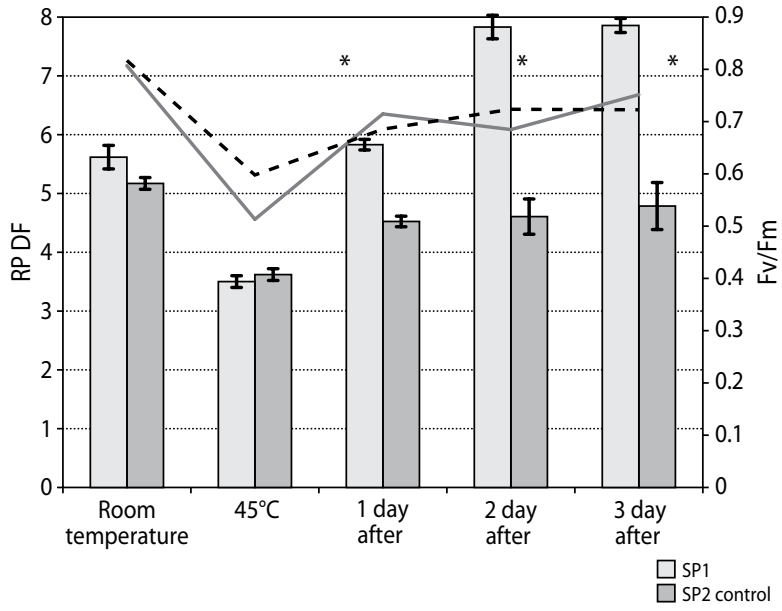

Figure 4. The average of relative delayed fluorescence (RP DF) and PSII quantum yield $\left(F_{\mathrm{v}} / F_{\mathrm{m}}\right)$ for the Scots pine needles being exposed to the temperature of $45^{\circ} \mathrm{C}$ in laboratory conditions, study periods: A - June; B - July; C - September

* Statistically significant differences $(\mathrm{P}<0.05)$ for $(\mathrm{RP} D F)$.

** Statistically significant differences $(\mathrm{P}<0.05)$ for $\left(F_{\mathrm{v}} / F_{\mathrm{m}}\right)$ and RP DF. determination of the quantitative content of pigments it was proved that after removing the damaging factor, the Scots pine assimilation apparatus can recover, while the rate of recovery depends on the impact force.

The above data are the result of short-term experiments, when the after-effects were observed within a few days. The question remains about the recovery period duration for the normal metabolism in the leaves, and the presence of acclimation effects at the organism level after stress and their duration. For that reason, we conducted experimental studies on the saplings of Pinus sylvestris L., being in the same climatic and soil conditions, but differing in the duration of post-fire period.

According to the classification by Kurbatsky (1962), model trees of the I age class Scots pine from a sample plot 1 (SP) experienced low-intensity ground fire, as the average flame height for the site did not exceed $0.5 \mathrm{~m}$.

During the experiment on the effects of stress temperatures $\left(43^{\circ} \mathrm{C}, 45^{\circ} \mathrm{C}\right.$ and $\left.47^{\circ} \mathrm{C}\right)$ on the branches of Scots pine, there was marked a reduction of the relative parameter of delayed fluorescence and the maximum quantum yield of PSII photochemistry in response to the action of temperature.

Natural heat resistance of plants depends on several factors, including the leaf age. According to G.I. Girs (1982), evergreens after overwintering lose age differences in heat resistance, so in our work we used the average values for 2- and 3-year-old needles, as heating embraced samplings fully, not partially.

Fluorescence indicators of Scots pine needles at room temperature $\left(\approx 24^{\circ} \mathrm{C}\right)$ do not show significant differences between the sample plots throughout the whole study period (Fig. 4 A, B, C). However, upon heating photosynthetic activity changes in varying degrees.

Figure 4 shows in detail the fast and delayed fluorescence parameters of the Scots pine needles growing on the sample plot after ground fire that occurred in May 2014 (SP1). Short 10-min heating of saplings at $45^{\circ} \mathrm{C}$ leads to the suppression of photosynthetic activity both among trees having grown in the control sample plot and the trees that were exposed to ground fire a year ago.

For samples taken in June 2015 (Fig. 4A), 10-min heating at the temperature of $45^{\circ} \mathrm{C}$ led to a decrease of the delayed fluorescence relative parameter against the control level by $18 \%$ for trees from the control plots and by $28 \%$ for trees exposed to heat during ground fire. 
The $F_{\mathrm{v}} / F_{\mathrm{m}}$ ratio also decreased in comparison with the control level. Even greater decrease was observed in photosynthetic activity for the needles from all plots the next day after heating. This reaction was possible due to the fact that the plants were in a phase of shoot growth, and the flow of plastic substances (metabolites) was directed to the support of growth. It may be due to the cells containing a smaller amount of the thermal protector. Recovery of photosynthetic activity almost to the control level occurred on 2-3 days with higher values of the delayed fluorescence and $F_{\mathrm{v}} / F_{\mathrm{m}}$ of needles exposed to stressful temperatures in the fire in 2014 (the differences were statistically significant for $p \leq 0.05$ ).

Figure $4 \mathrm{~B}$ shows the simulated effects of high temperature $\left(45^{\circ} \mathrm{C}\right)$ on chlorophyll fluorescence of pine needles that was investigated in July 2015. The parameter of delayed fluorescence at room temperature had the lowest values compared to the previous and subsequent period of study. It is known that photosynthesis is the thermolabile process, and falloff in intensity occurs at relatively low temperatures, which are not fatal to the cells (Konovalov and Semenov 1990). Thus, high daily average and daytime temperatures in July could have affected the decrease in photosynthetic activity as a whole. High daily average air temperature had no effect on the maximum quantum efficiency $\left(F_{\mathrm{v}} / F_{\mathrm{m}}\right)$, which was consistently high (about $0.7-0.8$ ), attesting to the high efficiency of the primary PSII photochemistry.

Ten-minute heating at the temperature of $45^{\circ} \mathrm{C}$ did not lead to a significant decrease of delayed fluorescence against the control level. Such thermal stability may result from early cell defense reactions in order to prevent damages due to high daytime temperatures. Trees in the summer vegetation phase are adapted to high air temperatures. Neither $F_{\mathrm{v}} / F_{\mathrm{m}}$ decreased by about $20 \%$ in relation to the initial levels for the needles of pine trees from all plots. Fig. 3B shows that 3 days after exposure to the damaging factor there was an increase in photosynthetic activity under the laboratory exposure against the control level. In contrast, the lower values were characteristic of the trees in the control plots, which were not exposed to fire. It may be concluded that ground fire in 2014 boosted the tree's ability of repair after the action of damaging temperatures had finished.

Data obtained for saplings selected in September are shown in Fig. 4B. During 10-minute heating of saplings at the temperature of $45^{\circ} \mathrm{C}$ there was equal sup- pression of photosynthesis of needles for the control area and for the area subjected to fire. Under the laboratory exposure $F_{\mathrm{v}} / F_{\mathrm{m}}$ ratio and the relative parameter of delayed fluorescence for needles from SP2 control are reestablished at the original level during the first experimental day. Repair of the photosynthetic activity of the needles from SP1 also happened on the first experimental day, at the same time on second and third days, on average $40 \%$ increase in fluorescence level was recorded in comparison to the control level, which is reflected in the increased relative parameter of delayed fluorescence. Such differences between the sample plots in response to short-term exposure to temperature above physiological optimum for photosynthesis may stem from the fire impact on SP1 forest stand in the past. So this could have conditioned the heat resistance of the needles, which is important for maintaining the functional activity after the stress and during repeated exposure to temperatures.

The value of the maximum quantum yield of $\left(F_{\mathrm{v}} / F_{\mathrm{m}}\right)$ photochemistry in the needles, which were selected in July and September, shows no significant differences between SP1 exposed to ground fire in 2014 and the control plot. Specifically, after repeated exposure to stress, the ratio $F_{\mathrm{v}} / F_{\mathrm{m}}$ remained the same for both tree plots. That is why the current study does not demonstrate the possible application of this parameter for estimating the duration of persistent metabolic changes in the trees.

Table 2. Chlorophyll $\mathrm{a}+\mathrm{b}$ and carotenoids content, $\mathrm{mg} / \mathrm{g}$ of dry weight

\begin{tabular}{|c|c|c|c|c|}
\hline & \multicolumn{2}{|c|}{$\begin{array}{l}\text { Chlorophyll } \mathrm{a}+\mathrm{b} \\
\text { content, } \\
\mathrm{mg} / \mathrm{g} \text { of dry weight }\end{array}$} & \multicolumn{2}{|c|}{$\begin{array}{l}\text { Carotenoids content, } \\
\text { mg/g of dry weight }\end{array}$} \\
\hline & SP1 & $\begin{array}{c}\text { SP2 } \\
\text { control }\end{array}$ & SP1 & SP2 control \\
\hline June & $2.26 \pm 0.12$ & $2.06 \pm 0.40$ & $0.29 \pm 0.02$ & $0.28 \pm 0.03$ \\
\hline July & $2.07 \pm 0.15$ & $2.24 \pm 0.11$ & $0.24 \pm 0.01$ & $0.25 \pm 0.004$ \\
\hline $\begin{array}{l}\text { Septem- } \\
\text { ber }\end{array}$ & $2.11 \pm 0.30$ & $2.19 \pm 0.30$ & $0.26 \pm 0.01$ & $0.25 \pm 0.03$ \\
\hline
\end{tabular}

The data of comparative analysis of the chlorophyll $a+b$ content (see Tab. 2) for the forest stand that experienced ground fire in 2014 (SP1) testify to the decrease in the number of pigments in July and September. According to Girs (1982), the following year after the fire, the chlorophyll content in needles at the beginning of 
the growing season (June) should exceed the control level, which is consistent with our data $(2.26 \mathrm{mg} / \mathrm{g}$ and $2.06 \mathrm{mg} / \mathrm{g}$ of dry weight for SP1 and SP2 control respectively). There were almost no vivid changes in the content of carotenoids in general after low-intensity fire damage. Differences in the quantitative content of the pigments are not statistically valid. Hence, we can conclude that the pigment complex is resistant to shortterm heating at high temperatures during the fire of low intensity, which ensures the preservation of functional activity after the stress.

\section{Conclusion}

The experimental studies revealed some differences in the dynamics of the needles' heat resistance during immediate exposure to damaging high temperatures and in the post-fire period. While registering the fluorescence parameters, it was found that certain physiological processes in plants can be modified by stressful events. These changes may have a positive effect in case of repeated stress factors.

Chlorophyll fluorescence may act as an indicator of structural and functional properties of photosynthetic membranes in the plant leaves. In particular, the relative parameter of delayed fluorescence may express the duration of conservation the metabolic changes of photosynthetic apparatus for several years after a fire, whereas the ratio of $F_{\mathrm{v}} / F_{\mathrm{m}}$ reflecting the PSII photochemical efficiency can be applied for registration of the immediate response of assimilation apparatus of the needles to heat stress.

\section{References}

Akres O., Cavallaro I., Cheng C., Dixon M., Hofbauer T., Mahr S. 2016. The Christmas tree project: Comparing the effects of five treatments on the health of cut Christmas trees (Pinus radiata, Pinaceae). Australian Journal of Botany, 64 (1), 15-19.

Bezkorovainaya I.N., Ivanova G.A., Bogorodskaya A.V., Krasnoshchekova E.N., Tarasov P.A. 2007. The nitrogen reserves in sandy podzols after controlled fires in pine forests of Central Siberia. Eurasian Soil Science, 40 (6), 700-707.
Francos M. 2016. The role of forest fire severity on vegetation recovery after 18 years. Implications for forest management of Quercus suber L. in Iberian Peninsula. Global and Planetary Change, 145, 11-16.

Certini G. 2005. Effects of fire on properties of forest soils: a review. Oecologia, 143 (1), 1-10.

Gavrilenko V.F., Zhigalova T.V. 2003. Large workshop in photosynthesis (in Russian with English summary). Academy, Moscow.

Girs G.I. 1982. Physiology weakened tree (in Russian with English summary). Nauka, Novosibirsk.

Grigoriev Y.S., Furyaev EA, Andreev A.A. 1996. Method for determination of phytotoxic substances (in Russian with English summary). Patent nr 2069851. Bul. Rec. 33.

Grigoriev Y.S., Andreev D.N. 2012. About the technique of registration of the chlorophyll delayed fluorescence of bioindication of the air pollution on coniferous (in Russian with English summary). Estestvennye Nauki, 2, 36-39.

Ivanova G.A., Conard S.G., McRae D.D. 2014. The impact of fire on components of the ecosystem of middle of pine forests of Siberia (in Russian with English summary). Nauka, Novosibirsk.

Kharuk V.I., Ponomarev E.I. 2016. Boreal forests in a changing climate: the dynamics of forest fires (in Russian with English summary). In.: Proccedings of Regional problems of remote sensing. Proceedings of the III International Scientific Conference, Krasnoyarsk, Russia 1, 38-41.

Konovalov V.N. Semenov B.A. 1990. The impact of fire on the physiological condition of the stands Far North. In.: Proccedings of Problems of forest science and forest ecology conference, I, Krasnoyarsk, Russia, 156-158.

Kovaleva N.M., Ivanova G.A. 2013. Recovery of ground vegetation at the initial stage of fire succession. Contemporary Problems of Ecology, 6 (2), 162-169.

Kurbatsky N.P. 1962. Technique and tactics of fighting forest fires (in Russian with English summary). Goslesbumizdadt, Moscow.

Lange O.L. 1964. The study of changes of heat-resistance in plants. The cell and the temperature of the medium. Nauka, Moscow.

Maxwell K., Johnson Giles N. 2000. Chlorophyll fluorescence - a practical guide. Journal of Experimental Botany, 51 (345), 659-668. 
McRae D.J., Conard S.G., Ivanova G.A., Sukhinin A.I., Baker S.P., Samsonov Y.N., Blake T.W. 2006. Variability of fire behavior fire effects and emissions in scotch pine forests of central Siberia. Mitigation and Adaptation Strategies for Global Change, 11, 45-74.

Molchanov A.G. 2012. An estimation of moisture availability influence on daytime variability of photosynthesis-light curves. Mathematical Biology and Bioinformatics, 7 (1), 197-205.

Murata N., Takahashi S., Nishiyama Y., Allakhverdiev S.I. 2007. Photoinhibition of photosystem II under environmental stress. Biochimica et Biophysica Acta (BBA) - Bioenergetics, 1767 (6), 414-421.

Owen K.A., Mark G.T. 2003. Thermal acclimation and the dynamic response of plant respiration to temperature. Trends in Plant Science, 8 (7), 343-351.

Ponomarev E.I., Valendik E.N., Kisilyakhov Y.K. 2012. Satellite monitoring of large scale wildfires in Siberia. In.: Proccedings of workshop on impact of climate change on forest and agricultural ecosystems and adaptation strategies, Krasnoyarsk, Russia, 1, 24.

Sudachkova N.E., Romanova L.I., Astrakhantseva N.V., Novoselova M.V., Kosov I.V. 2016. Stress Reactions of Scots Pine Trees to Injuring by Ground Fire. Contemporary Problems of Ecology, 5, 739-749.

Smits K.M. 2016. Experimental and modeling study of forest fire effect on soil thermal conductivity. Pedosphere, 26 (4), 462-473.

Tarasov P.A., Ivanov V.A., Ivanova G.A. 2008. Temperature regime of soils in Scots pine forests of central taiga burned by surface fires (in Russian with English summary). Conifers of the Boreal Area, 25 (3/4), 300-304.

Titov A.F., Talanov V.V. 2011. Local effect of high and low temperatures on plants (in Russian with English summary). Institute of Biology, Karelian Research Centre of Russian Academy of Sciences, Petrozavodsk.
Tsibart A.S., Gennadyev A. 2008. The impact of fire on forest soil properties Priamurja (in Russian with English summary). Soil Science, 7, 783-787.

Tsvetkov P.A. 2006. Nagar as a diagnostic sign (in Russian with English summary). Conifers of the Boreal Zone, 23 (3), 132-137.

Tsvetkov P.A. 2013. The impact of fire on the initial stage of forest recovery in the middle pine forests of Siberia (in Russian with English summary). Conifers of the Boreal Zone, 2, 15-21.

Turetsky M.R. Wieder R.K. 2001. A direct approach to quantifying organic matter lost as result of peatland wildfire. Can. J. of Forest Res., 31 (2), 363-366.

Valendik E.N, Sukhinin A.I., Kosov I.V. 2006. Influence of surface fires on the stability of coniferous species (in Russian with English summary). VN Sukachev SB RAS, Krasnoyarsk.

Valendik E.N., Kisilyakhov Ye. K., Ryzhkova V.A., Ponomarev E.I., Goldammer J.G. 2014. Forest fires under abnormal weather conditions in Central Siberia (in Russian with English summary). Siberian Forest Journal, 3, 43-52.

Valendik E.N., Kosov I.V. 2008. Stability of kidney conifer species to the effects of surface fires (in Russian with English summary). Forest Science, 5, 12-17.

Valendik E.N., Verkhovets S.V., Kisilyahov E.K., Ivanova G.A., Byuhanov A.V., Kosov I.V., Goldammer I.G. 2010. Technology of controlled burning in the forests of Siberia: the collective monograph (in Russian with English summary). SFU, Krasnoyarsk.

Wang R., Hu H.-Q. 2013. Physiological response of Betula platyphylla leaves to fire and the restoration after fire. Journal of Beijing Forestry University, 36 (1), 31-34.

Yamori W., Hikosaka K., Way D.A. 2014. Temperature response of photosynthesis in $\mathrm{C} 3, \mathrm{C} 4$, and CAM plants: temperature acclimation and temperature adaptation. Photosynthesis Research, 119 (1/2), 101-117. 